\title{
Childhood Intracranial Germinoma with Granulomatous Reaction
}

\section{Granülomatöz Reaksiyonun Eşlik Ettiği Çocukluk Çağı İntrakraniyal Germinomu}

\author{
Gülen GÜL NiFLioĞLU', Mehtat ÜNLÜ'1 , Nurullah YÜCEER ${ }^{2}$, Erdener ÖZER ${ }^{1}$
}

Departments of ${ }^{1}$ Pathology and ${ }^{2}$ Neurosurgery, Dokuz Eylül University, Faculty of Medicine, IZMIR, TURKEY

\begin{abstract}
Central nervous system tumors are the second most common type of childhood cancer in Turkey. Germinomas constitute two thirds of intracranial germ cell tumors. The granulomatous inflammation occurring around germinomas can cause histological diagnostic difficulty. We present a 12-year-old girl with a diagnosis of germinoma in the corpus callosum associated with granulomatous reaction to emphasize the diagnostic challenge which may occur during stereotactic biopsy interpretation or intraoperative consultation.
\end{abstract}

Key Words: Brain, Germ cell neoplasms, Germinoma, Granuloma, Corpus callosum

\section{INTRODUCTION}

The most common childhood tumors after acute leukemias $(27.5 \%)$ in our country are central nervous system (CNS) tumors $20.7 \%$ (1). Intracranial germ-cell tumors, which are a part of this group, make up a heterogenous tumor group seen in children and adolescents (2). The incidence peaks close to puberty. Patients under the age of 20 make up $90 \%$ of cases. The tumor is seen in the second decade of life at a rate of $65 \%$ (3). A study from our country has reported the intracranial germ-cell tumor incidence as $0.45 \%$ (4).

These rare tumors are morphological homologues of germinal tumors in the gonads (2-4). Granulomatous inflammation around the germinoma is a histological feature seen rarely in both gonadal and extragonal germinomas $(5,6)$. Granulomatous inflammation to a certain degree can sometimes accompany intracranial germinomas and cause diagnostic difficulty. One must consider the possibility that only the granulomatous inflammation area may be sampled especially during stereotactic biopsy attempts when a sample is obtained only focally from the mass. A similar

Received : 04.01.2010

Accepted : 11.05 .2010
ÖZ

Ülkemizde, santral sinir sistemi tümörleri çocukluk çağında ikinci sıklıkta görülmektedir. İntrakraniyal germ hücreli tümörlerin, üçte ikisini germinomlar oluşturur. Germinomların çevresinde granülomatöz inflamasyon görülmesi, histolojik olarak tanısal karışıklığa yol açabilir. Bu makalede granülomatöz reaksiyonun eşlik etmesi durumunda, germinomlarda stereotaksik ya da intraoperatif tanı zorluğu ortaya çıkabileceğini vurgulamak amacı ile, 12 yaşında bir kız hastada tanısı konan korpus kallosum yerleşimli bir germinom olgusu sunulmaktadır.

Anahtar Sözcükler: Beyin, Germ hücreli neoplazmlar, Germinom, Granülom, Korpus kallosum

diagnostic risk is present for intraoperative consultation. It is therefore necessary to evaluate an adequate amount of material with an adequate number of permanent sections during histopathological confirmation and neoplastic cells should be demonstrated with serial sections (5). The correct histopathological diagnosis is of tremendous importance as these tumors are sensitive to radiotherapy (7).

In this study, we report a germinoma case located in the corpus callosum in a 12-year-old girl. The tumor was accompanied by a granulomatous reaction which can make stereotactic and intraoperative diagnosis difficult and delay the appropriate treatment.

\section{CASE REPORT}

A 12-year-old female without known disease before presented at our hospital with headache, nausea and vomiting for the last 15 days. Physical examination revealed bilateral papillary stasis in the fundi while magnetic resonance (MR) investigation showed a tumoral mass $4 \times 4 \mathrm{~cm}$ in size with a cystic component on the corpus callosum.

Correspondence: Gülen GÜL NİFLİOĞLU

Department of Pathology, Dokuz Eylül University, Faculty of Medicine,

IZMIR, TURKEY

E-mail: drgulen@ymail.com Phone: +90 2324123420 
Two sections were sent for consultation during surgery and one was reported as a non-tumor lesion while the other as a malignant tumor. Permanent sections revealed that the mass was a heterogeneous tumor consisting of germinoma and granulomatous inflammation areas. The histological diagnosis was supported by immunohistochemical staining.

The total mass was processed for microscopical investigation and the sections showed marked lymphocytic infiltration with a septal distribution, and large, uniform tumor cells distributed in clusters. Tumor cells had

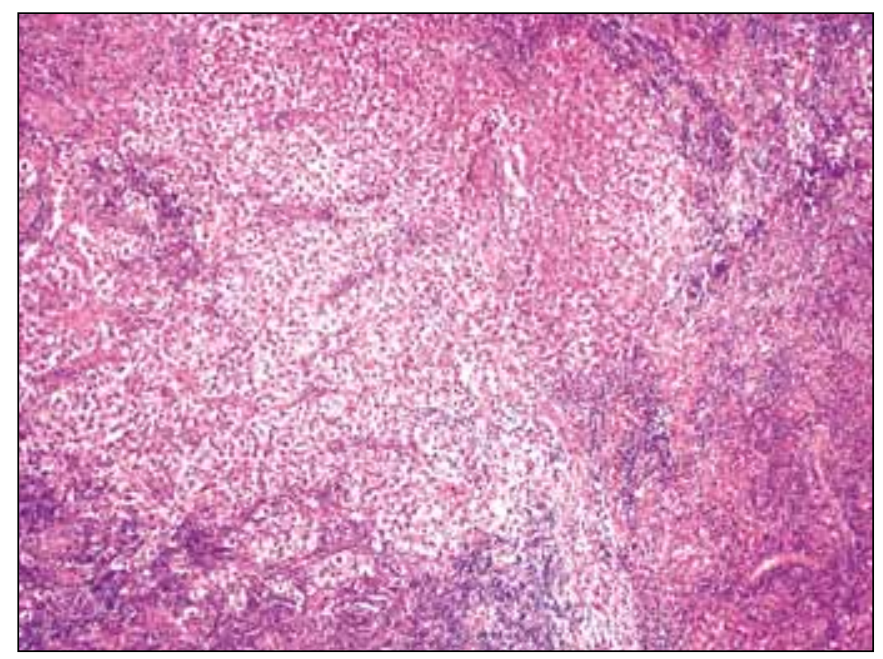

Figure 1: Histological appearance of germinoma. Dense lymphocytic infiltration with septal distribution and scattered large, uniform tumor cells in clumps are observed (H\&E; x100).

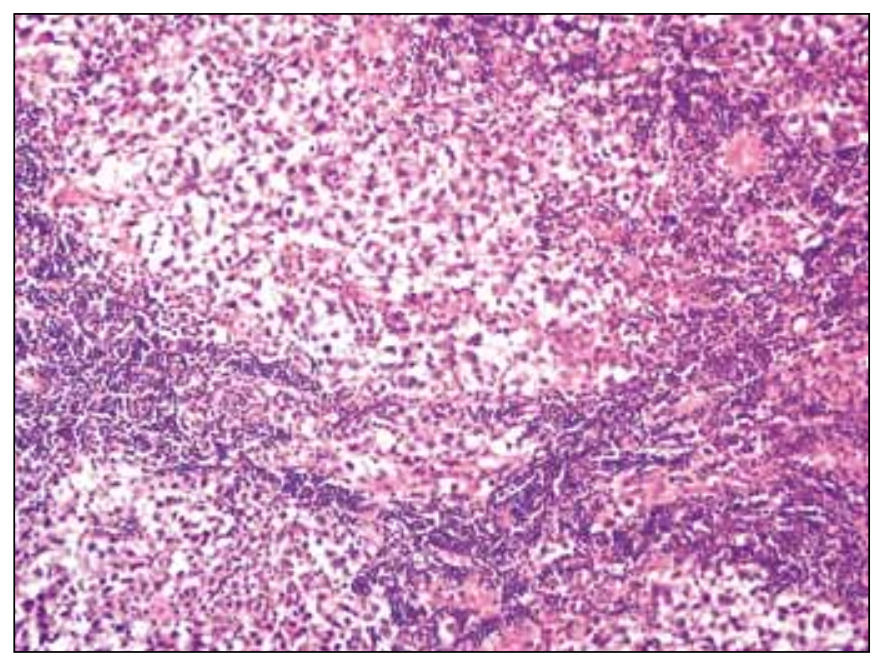

Figure 2: Histological appearance of germinoma. The tumor cells have a large nucleus, prominent nucleoli and clear cytoplasm (H\&E; x200). large nuclei, prominent nucleoli and a clear cytoplasm. (Figure 1 and 2). These cells showed negative staining with glial acidic fibrillary protein (GFAP) and positive staining with placental alkaline phosphatase (PLAP) on immunohistochemistry tests (Figure 3). We also observed a granulomatous reaction consisting of multinucleated giant cells, epithelioid histiocytes and lymphocytes in the adjacent area (Figure 4). The giant cells stained positive with CD68 antibody but negative with GFAP. The tumor was diagnosed as germinoma with these morphological and immunohistochemical features.

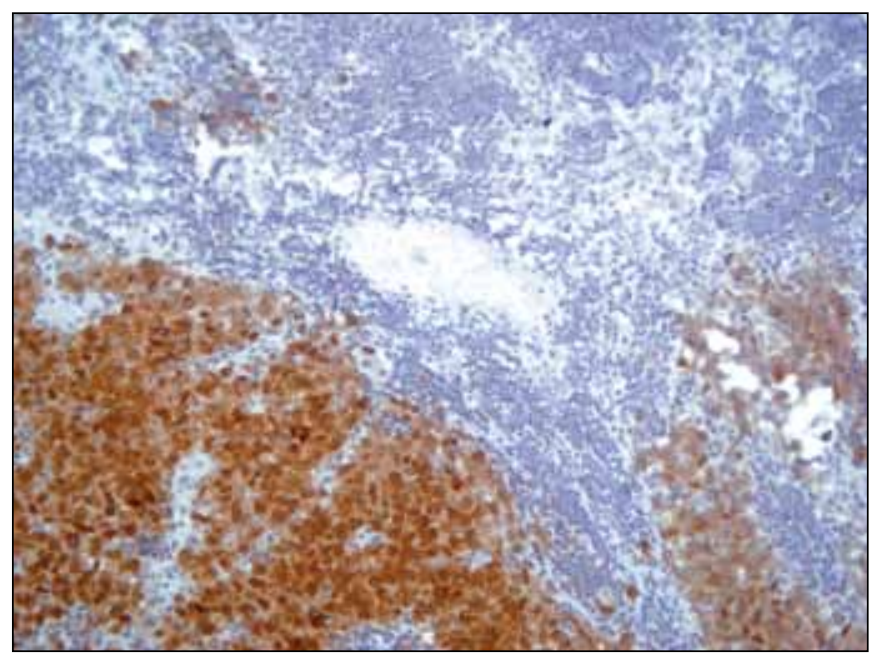

Figure 3: Tumor cells showing positive staining with PLAP antibody (x200).

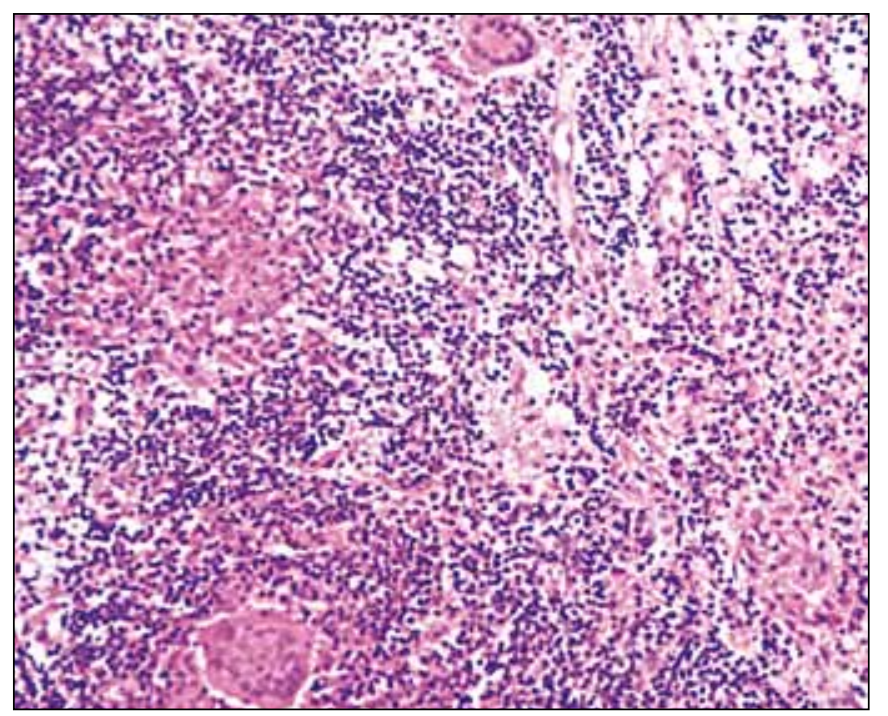

Figure 4: Granulomatous areas consisting of multinuclear giant cells, epithelioid histiocytes and lymphocytes accompanying the germinoma (H\&E; x200). 


\section{DISCUSSION}

Germ cell tumors of the CNS are rare but are seen relatively more commonly in some geographical regions. The reported incidence of this tumor from our country is similar to figures found in series from Western countries (4).

Clinical presentations of germ cell tumors depend on the central nervous system localization, lesion size and patient age $(3,4)$. The incidence peaks close to puberty. Patients younger than 20 make up $90 \%$ of the cases. The disease is seen in the second decade of life in $65 \%$ of the patients (3).

Germinomas make up two-thirds of intracranial germ cell tumors (7). Then tend to be located in the midline, similar to other extragonadal germ cell tumors. At least $80-90 \%$ of cases located in the central nervous system develop in the midline axis from the suprasellar cistern and infundibulum to the pineal gland. They are two times more common in males when all involvement areas are considered (3). CNS germ cell tumors are thought to develop from primordial germ cells that show aberrant migration from the fetal yolk sac during central neuroaxis development. A similar histogenesis is suggested for germinomas that are in the same tumor group (3).

A granulomatous reaction can accompany both gonadal and extragonadal germinomas. This histological change is thought to reflect the immune response of the host against neoplasia (5). Most of the lymphocytes within the germinoma tissue carry $\mathrm{T}$ lymphocyte surface antigen. The lymphocytes infiltrating the tumor show a spontaneous cytotoxic reaction against the tumor cells and therefore play a role in regulating tumor proliferation. Lymphocytes also trigger monocyte adhesion and aggregation by producing chemical mediators such as TNF and IFN. T lymphocytes therefore play a role both in killing the tumor cells and in the development of giant cells and granulomas in the germinomas (5).

The granulomatous reaction seen around germinomas is usually not sufficient to obscure the histological diagnosis. However, intracranial germinomas can sometimes be accompanied by significant granulomatous inflammation that can make the diagnosis difficult. The incidence and clinical characteristics of this granulomatous inflammation has not yet been fully investigated (6). A study on 43 cases in the literature has reported a granulomatous reaction in $4.7 \%$ of intracranial germinoma cases $(8,9)$. This may look like a significant rate but central nervous system biopsies are rarely encountered in daily practice. A study from our country has reported the incidence of central and peripheral nervous system tumors within all biopsies and surgical material as $0.51 \%(10)$. The granulomatous reaction area that can accompany these rare tumors can lead to diagnostic errors unless adequate tissue and serial sections are available.

MR investigation of germinomas shows contrast-enhancing masses with a dense cellular content. A cystic component or increased heterogeneity on radiology increases the possibility of a non-germinoma tumor. However, a germinoma accompanied by a chronic granulomatous inflammation should be suspected in this case (5).

Stereotactic biopsy is an important diagnostic method which enables tissue sampling from tumors with an intracranial location and has a morbidity risk of $0-0.5 \%$ (4). However, stereotactic biopsy interventions where the mass is targeted in a focal manner should take into account the possibility of obtaining a sample from the granulomatous inflammation area only. There is a similar diagnostic risk for intraoperative consultation. One must make sure the sample is obtained correctly from the mass and clinicopathological correlation should be present. An adequate amount of material should be evaluated with a sufficient number of permanent sections for histopathological verification and neoplastic cells should be demonstrated on serial sections (5).

Germinomas have a good prognosis in general, whether in the central nervous system or gonads. The general survival rate for germinomas is up to $91-97 \%$. More than $90 \%$ of the patients can be effectively treated with radiotherapy (7). One study has associated the presence of syncytiotrophoblastic giant cells in germinomas with decreased survival following radiotherapy (3). The effectiveness of radiotherapy is unknown in germinomas with granulomatous reaction but it has been reported to lead to a favorable prognosis (5). Open surgical intervention can be considered to treat the acute mass effect in germinomas accompanied by a chronic granulomatous inflammation. Radiotherapy may not be as effective in germinomas with granulomatous reaction as in other germinomas if there is no mass effect (5). In conclusion, considering the effective treatment the possibility of accompanying conditions such as granulomatous reaction that can cause difficulties in the differential diagnosis of germinomas should be noted.

\section{REFERENCES}

1. Ertan AE, Şengelen M, Vaizoğlu SA: Önlenebilir çocukluk çağg kanserleri. Cumhuriyet Univ Tip Fak Derg 2004, 26: 48-54

2. Binatlı AÖ, Erel U, Özhan İ, Altınel D, Ümit Bayol Ü, Özdamar N: Germinom: Bir vaka sunumu. Türk Nöroşir Derg 2007, 17: 206-211

3. Rosenblum MK, Bilbao JM, Ang LC: Neuromuscular System. In: Rosai and Ackerman's Surgical Pathology. J Rosai (ed), 9th ed. St. Louis, 2004, Elsevier Saunders, 2583-2584 
4. Bayındır Ç, Tanık C, Filizel F, Karasu A: Birincil kafa içi "germ" hücresi tümörleri. Turk Neurosurg 1997, 7: 5-8

5. Moon KS, Jung S, Lee MC, Cheon HC, Kim IY, Lee JK, Kim TS, Kang SS: Two cases of pineal germinoma with granulomatous inflammation. J Clin Neurosci 2005, 12: 310-313

6. Utsuki S, Oka H, Tanizaki Y, Kondo K, Kawano N, Fujii K: Pathological features of intracranial germinomas with reference to fibrous tissue and granulomatous change. Brain Tumor Pathol 2005, 22: 9-13

7. van Battum P, Huijberts MS, Heijckmann AC, Wilmink JT, Nieuwenhuijzen Kruseman AC: Intracranial multiple midline germinomas: is histological verification crucial for therapy? Neth J Med 2007, 65: 386-389
8. Endo T, Kumabe T, Ikeda H, Shirane R, Yoshimoto T: Neurohypophyseal germinoma histologically misidentified as granulomatous hypophysitis. Acta Neurochir 2002, 144: 1233-1237

9. Mueller W, Schneider GH, Hoffmann KT, Zschenderlein R, von Deimling A: Granulomatous tissue response in germinoma, a diagnostic pitfall in endoscopic biopsy. Neuropathology 2007, 27: 127-132

10. Gün BD, Burak Bahadır B, Gamze Numanoğlu G, Kuzey GM, Açıkgöz B, Özdamar ŞO: Zonguldak Karaelmas Üniversitesi Tip Fakültesi Patoloji Anabilim Dalı’nda 2002-2006 yılları arasında tanı alan sinir sistemi tümörleri. Türk Patol Derg 2007, 23: 93-97 